Article

\title{
A New Synthetic Route to Polyhydrogenated Pyrrolo[3,4- $b]$ pyrroles by the Domino Reaction of 3-Bromopyrrole-2,5-Diones with Aminocrotonic Acid Esters
}

\author{
Khidmet Shikhaliev ${ }^{1}$, Artem Sabynin ${ }^{1}$, Valeri Sekirin ${ }^{1}$, Michael Krysin ${ }^{1, *} \mathbb{D}^{\mathbb{D}}$, Fedor Zubkov ${ }^{2}$ \\ and Kristina Yankina ${ }^{2}$ \\ 1 Department of Organic Chemistry, Faculty of Chemistry, Voronezh State University, 1 Universitetskaya sq., \\ Voronezh 394018, Russia; chocd261@chem.vsu.ru (K.S.); artemsabynin@rambler.ru (A.S.); \\ sekirin.valeriy@mail.ru (V.S.) \\ 2 Department of Organic Chemistry, Faculty of Physics and Mathematics and Natural Sciences, RUDN \\ University, 6 Miklukho-Maklaya St., Moscow 117198, Russia; fzubkov@sci.pfu.edu.ru (F.Z.); \\ aleksandrina21@mail.ru (K.Y.) \\ * Correspondence: kaf261@rambler.ru; Tel.: +7-903-651-7482
}

Received: 4 November 2017; Accepted: 20 November 2017; Published: 22 November 2017

\begin{abstract}
A new synthetic approach to polyfunctional hexahydropyrrolo[3,4-b]pyrroles was developed based on cyclization of $\mathrm{N}$-arylbromomaleimides with aminocrotonic acid esters. A highly chemo- and stereoselective reaction is a Hantzsch-type domino process, involving the steps of initial nucleophilic C-addition or substitution and subsequent intramolecular nucleophilic addition without recyclyzation of imide cycle.
\end{abstract}

Keywords: pyrrole; pyrrolo[3,4-b]pyrrole; bromomaleimide; aminocrotonate; domino reaction

\section{Introduction}

Bicyclic pyrrolopyrroles are the core of numerous compounds with various useful properties. For example, they are used as optoelectronic materials [1,2], pigments for varied purposes [3-6], and are characterized by a variety of biological activities [7,8]. Inhibitors of protein methyltransferases [9], glycosyltransferases [10], agonists of various serotonin 5-HT-receptors [11-13], antagonists of integrin VLA-4 [14], and promising structural analogs of antibacterial fluoroquinolones [15] have been found among the derivatives of hydrogenated pyrrolo[3,4-b]pyrroles, thereby causing a significant interest in the search for new synthetic approaches to this heterocyclic system.

The most common strategy for its construction from non-cyclic precursors (Scheme 1, Route A) is based on a multistage synthesis of $\mathrm{N}$-alkenyl tethered aldehydes, which are further subjected to intramolecular cyclization with $\alpha$-amino acids via the formation of azomethine ylides [11,12,16-21]. Hydrogenated pyrrolo[3,4- $b$ ]pyrroles are also formed as a result of intramolecular 1,3-dipolar cycloaddition in phosphorus-containing azomethine ylides generated in situ from alkene-tethered imines, acid chlorides and phosphonites [22], or transition metal promoted carbonilative [2+2+1] carbocyclization of $\mathrm{N}$-allene imines [23,24]. 

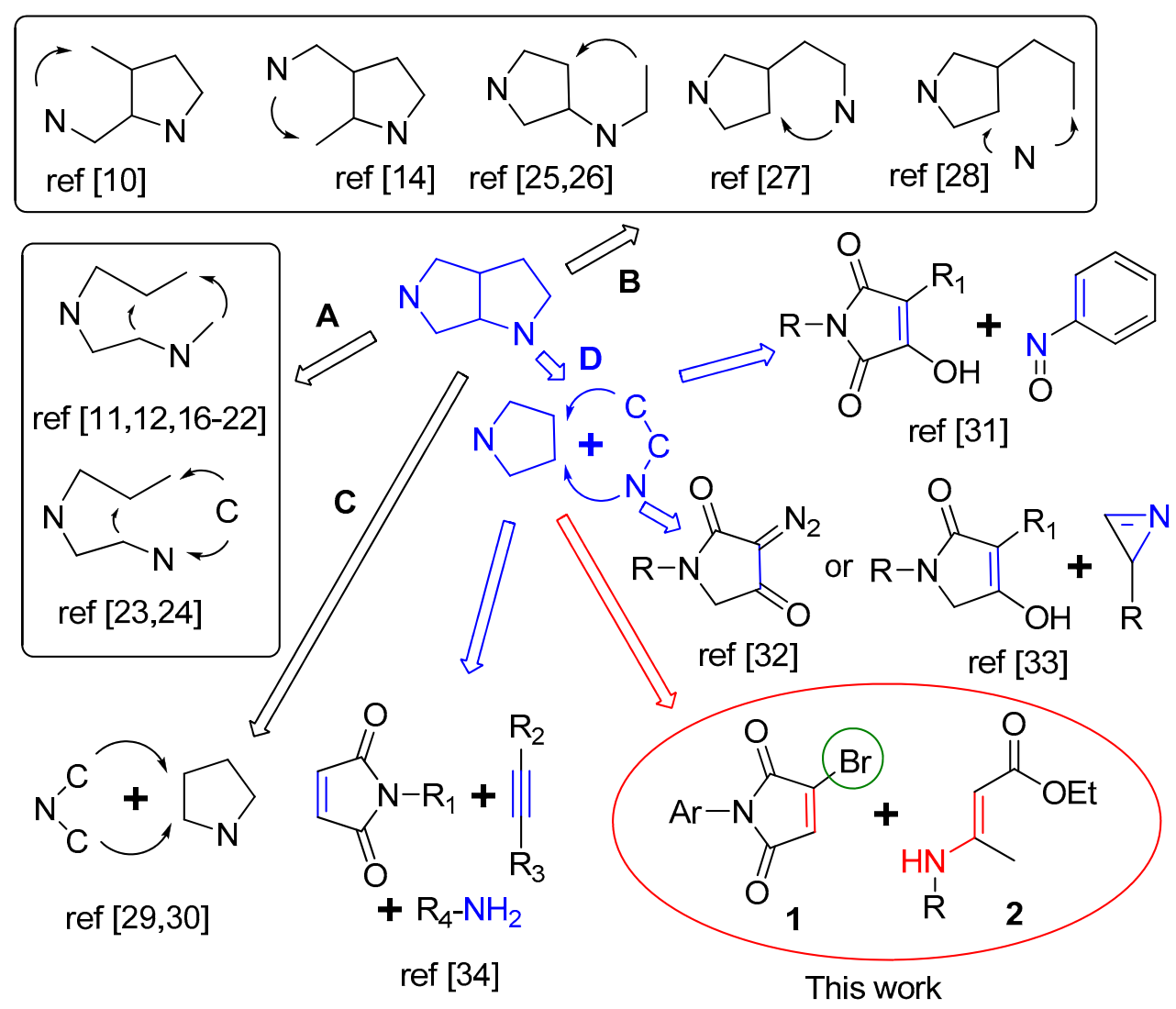

Scheme 1. Retrosynthetic routes to pyrrolo[3,4-b]pyrroles.

Another direction in the synthesis of pyrrolo[3,4-b]pyrroles is the anellation of the second pyrrole ring. Examples of such reactions include intramolecular amidation [10,14], alkylation [25], condensation [26], nucleophilic addition [27], and Paal-Knorr heterocyclization [28] in appropriately substituted pyrroles (Scheme 1, Route B). Intermolecular convergent approaches to this heterocyclic system have been realized to a much lesser extent. Thus, the dipolarophilic pyrrole derivatives are anellated over the $b$ bond as a result of the 1,3-dipolar cycloaddition of azomethine ylides, generated from silylated hemiaminals [29] or aziridines [30] (Scheme 1, Route C). Hexahydropyrrolo[3,4-b]indoles were obtained as a result of organocatalytic asymmetric anellation of N-hydroxymaleimides with nitrosobenzene [31]. Synthetic equivalents of $\mathrm{C}-\mathrm{C}-\mathrm{N}$ synthon are also $2 \mathrm{H}$-azirines, which form hexahydropyrrolo[3,4-b]pyrroles in $\mathrm{Cu}$-catalyzed domino-reactions with tetramic acid derivatives [32,33]. Oxidative cyclization of maleimides with amines and alkyne esters is also catalyzed by copper (I) salts [34] (Scheme 1, Route D). It should be noted that almost all of these reagents are not readily available.

In continuation of our research on the synthesis of heterocycles based on cyclic imides of unsaturated dicarboxylic acids $[35,36]$, in the present work we report the unusual domino reaction of 1-aryl-3-bromo- $1 \mathrm{H}$-pyrrole-2,5-diones (bromomaleimides) (1) with N-substituted esters of $\beta$-aminocrotonic acids (2) for the metal-free preparation of a series of new hexahydropyrrolo[3,4-b]pyrroles.

\section{Results and Discussion}

One of the most interesting applications of maleimides, which do not have substituents on the $\mathrm{C}=\mathrm{C}$ bond, in the synthesis of heterocyclic compounds are domino-recyclization reactions with a variety of dinucleophilic reagents [37-39]. Despite the presence of three electrophilic centers in their structure (one of the double bond carbon atoms and two carbonyl $\mathrm{C}$ atoms), a fairly high regioselectivity was 
noted for similar reactions, in particular, with aminocrotonic acid esters as 1,3-C,N-dinucleophiles [40]. Our choice of 1-aryl-3-bromo-1H-pyrrole-2,5-diones (1a-d) is due, on the one hand, to their easy synthetic availability [41] and, on the other hand, the appearance of yet another, compared to the C-unsubstituted maleimides, electrophilic C-atom, to which a bromine atom is bound, which significantly expands the variety of possible transformations. N-substituted ethyl aminocrotonates $(\mathbf{2 a}-\mathbf{c})$, also easily synthesized by known methods [42,43], were chosen for the purpose of structural diversification of the target substances (Scheme 2).
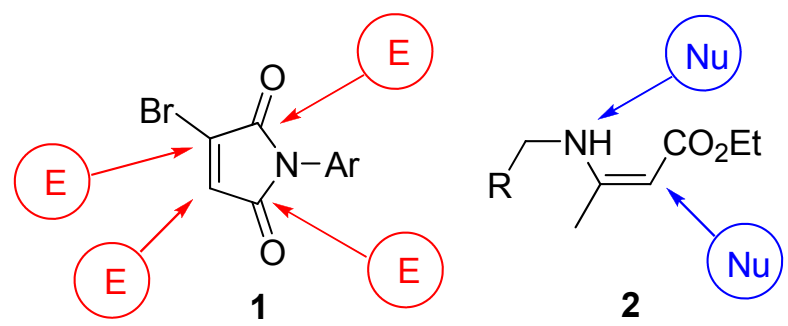

Scheme 2. Reaction centers in bromomaleimides (1) and aminocrotonates (2).

According to the well-known literature data on the reactions of maleimides with 1,3-C,N-dinucleophiles [35,37,40], we assumed that the most probable direction of interaction of bromomaleimides (1) with aminocrotonates (2) will be a Michael-type reaction, followed by intramolecular transamidation with simultaneous recyclization of the imide cycle in an intermediate (3). Depending on the carbonyl atom at which the last reaction takes place, either dihydropyrroles (4) or tetrahydropyridines (6) can form. Their dehydrobromination can lead to pyrrolinone (5) or pyridinone (7) (Scheme 3).

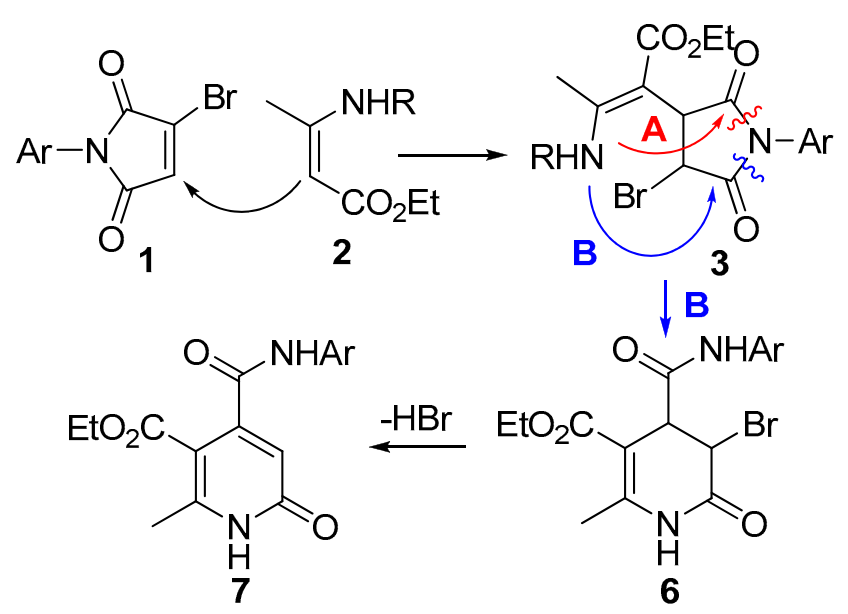<smiles>CCOC(=O)C1=C(C)NC(=O)C1=CC(=O)NC(=O)C(C)CC(C)C</smiles>

Scheme 3. Probable direction of reclyzation of $\mathbf{1 .}$

Monitoring of the reaction conditions for the example of $\mathbf{1 a}$ and $\mathbf{2 a}$ by TLC showed that, for their reactions, stirring in methanol without heating for $5 \mathrm{~h}$ is sufficient. Similar results were obtained in acetic acid, but the product yield was lower. In other solvents (chloroform, ethyl acetate, benzene, and dioxane), either reagent conversion was insignificant under the given conditions or a complex mixture of substances was observed to form when heated. In a 1a/2a molar ratio of 1:1, part of the starting bromomaleimide does not react, while the aminocrotonate reacts completely. Total conversion of bromomaleimide is achieved with a molar ratio of reactants of 1:2. The second molecule of aminocrotonate probably binds the hydrogen bromide liberated during the reaction. The reaction at a reactant molar ratio of 1:1 and the same amount of the 
additional base $\left(\mathrm{Et}_{3} \mathrm{~N}\right.$ or pyridine) resulted in the formation of tar products with a significant decrease in the yield of the target substances. Thus, only one product was formed: $(3 a S, 6 a R)$-ethyl 1-benzyl-2-methyl-4,6-dioxo-5-phenyl-1,3a,4,5,6,6a-hexahydropyrrolo[3,4-b]pyrrole-3-carboxylate (8a) instead of the expected 4-7 (Scheme 4).

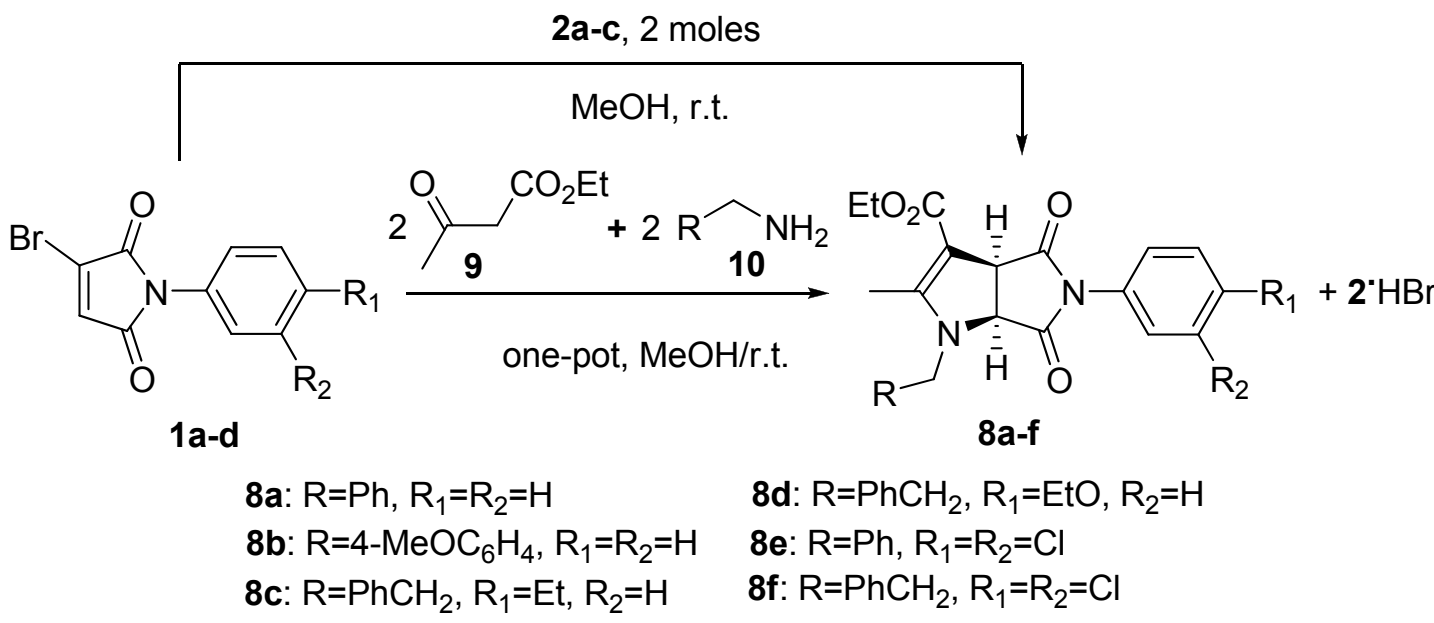

Scheme 4. Reaction between 1 and 2 .

Considering the simplicity of obtaining 2, we attempted multicomponent one-pot synthesis of pyrrolopyrroles (8). Preliminarily, the mixture of equimolar amounts of ethyl acetoacetate (9) and appropriate amine (10) was stirred for $24 \mathrm{~h}$, after which, without isolation of the resulting aminocrotonate, a methanol solution of half the amount of corresponding brommaleimide was added to the solution. Stirring was continued for 4 to $6 \mathrm{~h}$ (TLC control). The yields of the target substances isolated by simple filtration proved to be comparable with the two-component variant (Table 1).

Table 1. Reaction of $\mathbf{1}$ with 2.

\begin{tabular}{cccccc}
\hline Entry & Bromomaleimide, $\mathbf{A r}$ & Aminocrotonate, & Product & Time (h) & Yields ${ }^{\mathbf{1}}$ (\%) \\
\hline 1 & $\mathrm{Ph}(\mathbf{1 a})$ & $\mathrm{Ph}(\mathbf{2 a})$ & $\mathbf{8 a}$ & 5 & $46 / 53$ \\
2 & $\mathrm{Ph}(\mathbf{1 a})$ & $4-\mathrm{MeOC}_{6} \mathrm{H}_{4}(\mathbf{2 b})$ & $\mathbf{8 b}$ & 5 & $77 / 69$ \\
3 & $4-\mathrm{EtC}_{6} \mathrm{H}_{4}(\mathbf{1 b})$ & $\mathrm{PhCH}_{2}(\mathbf{2 c})$ & $\mathbf{8 c}$ & 4 & $82 / 74$ \\
4 & $4-\mathrm{EtOC}_{6} \mathrm{H}_{4}(\mathbf{1 c})$ & $\mathrm{PhCH}_{2}(\mathbf{2 c})$ & $\mathbf{8 d}$ & 6 & $73 / 70$ \\
5 & $3,4-\mathrm{Cl}_{2} \mathrm{C}_{6} \mathrm{H}_{3}(\mathbf{1 d})$ & $\mathrm{Ph}(\mathbf{2 a})_{8 \mathbf{c}}$ & $\mathbf{8 f}$ & 6 & $70 / 64$ \\
6 & $3,4-\mathrm{Cl}_{2} \mathrm{C}_{6} \mathrm{H}_{3}(\mathbf{1 d})$ & $\mathrm{PhCH}_{2}(\mathbf{2 c})$ & $69 / 61$ \\
\hline
\end{tabular}

In the ${ }^{1} \mathrm{H}$ NMR spectra of pyrrolopyrroles $(\mathbf{8 a}-\mathbf{f})$, in addition to the well identifiable signals of the substituents, there are a doublet of doublets or broadened doublet of H-6a (about 4.30 ppm with the vicinal spin-spin coupling constants $\mathrm{J}_{\mathrm{H}-3 \mathrm{a}-\mathrm{H}-6 \mathrm{a}} \sim 10.5 \mathrm{~Hz}$ and the long W-constant ${ }^{4} \mathrm{~J}_{\mathrm{H}-\mathrm{C}-\mathrm{N}^{1}-\mathrm{C}-\mathrm{H}^{6 \mathrm{a}}}$ $\sim 1.0 \mathrm{~Hz}$ ), as well as the doublet $\mathrm{H}-3 \mathrm{a}$ at $\sim 4.50 \mathrm{ppm}$ for $\mathrm{N}^{1}$-benzyl derivatives $\mathbf{8 a}, \mathbf{b}, \mathbf{e}$ and $\sim 4.75$ ppm for $\mathrm{N}^{1}$-phenethyl derivatives $8 \mathbf{c}, \mathbf{d}, \mathbf{f}\left(\mathrm{J}_{\mathrm{H}-3 \mathrm{a}-\mathrm{H}-6 \mathrm{a}} \sim 10.5 \mathrm{~Hz}\right)$. It is the multiplicity of the proton signal H-6a that proves its location. Diastereotopic are methylene protons, which are part of the benzyl, ester and phenethyl groups, causing the last two groups of complex type of appropriate signals. The absence of NH-signals excludes the formation of alternative compounds 4-7 (Scheme 3).

Conclusions on the arrangement of the substituents, based on ${ }^{1} \mathrm{H}$ NMR data, are confirmed by the results of $\mathrm{X}$-ray analysis of $\mathbf{8 c}$ (Figure 1; non-hydrogen atoms are represented by probabilistic ellipsoids of atomic displacements $(p=0.5)$ ). Thus, the interaction of $\mathbf{1}$ with 2 proceeds chemo- and stereoselectively without recycling of the imide cycle and leads to the formation of hexahydropyrrolopyrroles (8) with two adjacent quaternary asymmetric centers in their structure. 
The polyelectrophilic character of $\mathbf{1}$ and the dinucleophilic character of 2a (Scheme 2) cause a variety of possible variants of the initial interaction of the reagents and the direction of further transformations, both with opening and without opening the imide cycle. In our opinion, only two reasonable synthetic schemes can lead to the formation of $\mathbf{8 a - f : ~ ( a ) ~ a ~ M i c h a e l - t y p e ~ n u c l e o p h i l i c ~}$ C-addition of amino crotonate at the C-4 maleimide atom followed by dehydrobromination of succinimide (3) and a subsequent intramolecular cyclization of the intermediate $\mathbf{1 1}$ as a result nucleophilic addition with the participation of the nitrogen atom of the enamine fragment (Path $\mathrm{A})$; or (b) direct nucleophilic substitution of the bromine atom in the imide $\mathbf{1}$, also involving the $\mathrm{C}$ atom of the aminocrotonate and the subsequent analogous cyclization (Path B) (Scheme 5).

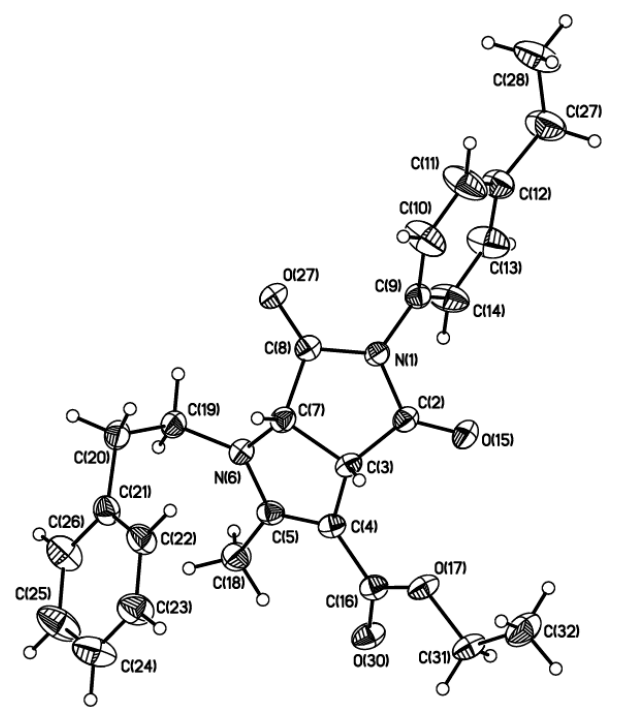

Figure 1. Molecular structure of pyrrolopyrrole (8c).

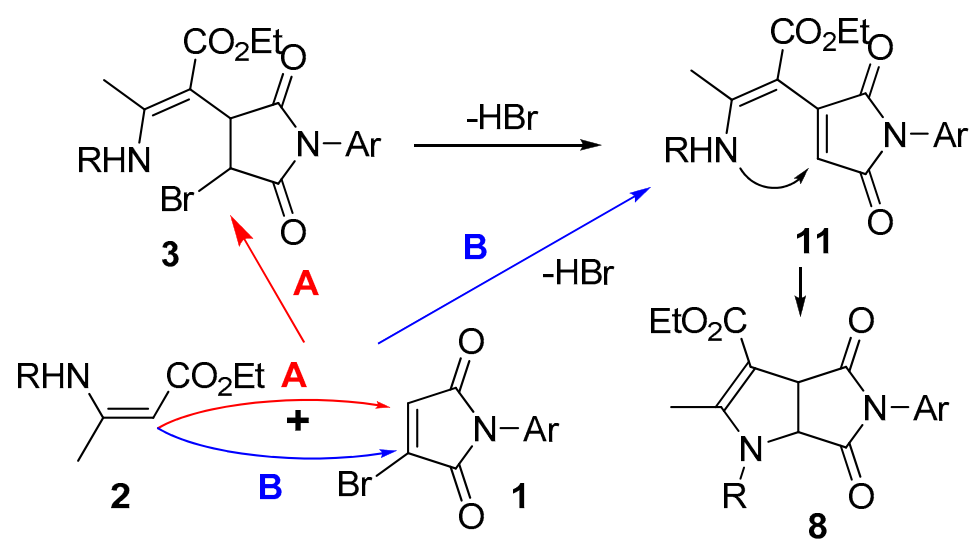

Scheme 5. Possible sequences of reactions in the cascade formation of pyrrolopyrroles (8).

In the first direction, for example, base-catalyzed arylation of 1a by 2-naphthols occurs [44]. Direction B is essentially a new, unusual version of the synthetic realization of the $\mathrm{C}-\mathrm{C}-$ dielectrophil + $\mathrm{C}-\mathrm{C}-\mathrm{N}$-dinucleophil retrosynthetic scheme of the well-known method for the production of pyrroles by the Hantzsch reaction (interaction of $\alpha$-halocarbonyl with $\beta$-enaminocarbonyl compounds $[45,46]$ ). The structural prerequisite for substantiating the possibility of using this approach for the synthesis of 8 is the high mobility of the bromine atom in bromomaleimides in reactions with nucleophilic reagents [47]. 


\section{Materials and Methods}

\subsection{General}

NMR ${ }^{1} \mathrm{H}$ and ${ }^{13} \mathrm{C}$ spectra were registered on Bruker DRX (500 and $125.8 \mathrm{MHz}$, respectively) spectrometer in DMSO- $d_{6}$, internal standard is TMS. Mass spectra were registered on Agilent Technologies LCMS 6230B (ESI, Agilent Technologies, Santa Clara, CA, USA). Melting points were determined on Stuart SMP 30. Control of reagent and product individuality, and qualitative analysis of reaction mass, was performed by TLC on Merck TLC Silicagel $60 \mathrm{~F}_{254}$ chromatographic plate (Merck KGaA, Darmstadt, Germany); eluents: methanol, chloroform, and their mixtures in various ratios. The chromatograms were developed by UV and iodine vapor.

Purity of the products was controlled by high performance liquid chromatography with high resolution mass-spectrometric detection under electrospray ionization (HPLC-HRMS-ESI) in combination with UV detection. The device consists of liquid chromatograph-Agilent 1269 Infinity and time-of-flight high resolution mass detector-Agilent 6230 TOF LC/MS (Agilent Technologies, Santa Clara, CA, USA). Block ionization is double electrospray, and the detection mass range is from 50 to 2000 Dalton. Capillary voltage is $4.0 \mathrm{kV}$, fragmentor $+191 \mathrm{~V}$, skimmer $+66 \mathrm{~V}$, OctRF 750 V. Column Poroshell 120 EC-C18 $(4.6 \times 50 \mathrm{~mm} ; 2.7 \mathrm{mkm})$ was used. Gradient eluation: acetonitrile/water $(0.1 \%$ formic acid); flow rate: $0.4 \mathrm{~mL} / \mathrm{min}$. Software for collection and elaboration of research results is MassHunter Workstation/Data Acquisition V.06.00. Starting bromomaleimides (1) and aminocrotonates (2) were provided by Alinda Chemical Ltd., Moscow, Russian Federation. Other reagents were purchased from commercial suppliers and used as received.

3.2. General Procedure for the Reaction of Bromomaleimides (1) with Aminocrotonates (3) and Characterization Data of Pyrrolo[3,4-b]pyrroles (8a-f)

Two-component reaction. A mixture of the corresponding bromomaleimide $(0.002 \mathrm{~mol})$ and aminocrotonate $(0.004 \mathrm{~mol})$ in $5 \mathrm{~mL}$ of methanol was stirred for 4 to $6 \mathrm{~h}$. The precipitate which formed was filtered off and recrystallized from methanol.

One-pot sequence. A mixture of acetoacetic ester (9) (0.004 mol) and amine (10) (0.004 mol) in $3 \mathrm{~mL}$ of methanol was stirred for $24 \mathrm{~h}$, after which, without isolation of the resulting aminocrotonate, a solution of the corresponding bromomaleimide $(0.002 \mathrm{~mol})$ in $5 \mathrm{~mL}$ of methanol was added. Stirring was continued for 4-6 h. The precipitate formed was filtered off and recrystallized from methanol. Hexahydropyrrolo[3,4-b]pyrrole (8) was obtained as colorless crystalline powders.

(3aS,6aR)-Ethyl 1-benzyl-2-methyl-4,6-dioxo-5-phenyl-1,3a,4,5,6,6a-hexahydropyrrolo[3,4-b]pyrrole-3carboxylate 8a. 0.36 g; yield 46\%; m.p. $141-142{ }^{\circ} \mathrm{C} ;{ }^{1} \mathrm{H}$ NMR (DMSO-d $\left.d_{6}\right), \delta$ (ppm): $1.20(3 \mathrm{H}, \mathrm{t}, J=7.1 \mathrm{~Hz}$, $\left.\mathrm{CH}_{3} \mathrm{CH}_{2} \mathrm{O}\right) ; 2.31$ (3H, s, $\left.\underline{\mathrm{CH}}_{3}-\mathrm{Het}\right) ; 4.00-4.14\left(2 \mathrm{H}, \mathrm{m}, \mathrm{CH}_{3} \mathrm{CH}_{2} \mathrm{O}\right) ; 4.33(1 \mathrm{H}, \mathrm{dd}, J=10.5 \mathrm{~Hz}, J=0.8 \mathrm{~Hz}$, H-6a); 4.53 (1H, d, J = $10.5 \mathrm{~Hz}, \mathrm{H}-3 \mathrm{a}) ; 4.59\left(1 \mathrm{H}, \mathrm{d}, J=16.7 \mathrm{~Hz}, \mathrm{CH}_{2} \mathrm{Ph}\right) ; 4.80\left(1 \mathrm{H}, \mathrm{d}, J=16.7 \mathrm{~Hz}, \mathrm{CH}_{2} \mathrm{Ph}\right)$; 7.23-7.26 (4H, m, $\left.\mathrm{CH}_{\text {arom }}\right) ; 7.30-7.34\left(1 \mathrm{H}, \mathrm{m}, \mathrm{CH}_{\text {arom }}\right) ; 7.38-7.44\left(3 \mathrm{H}, \mathrm{m}, \mathrm{CH}_{\text {arom }}\right) ; 7.47-7.51(\overline{\mathrm{2H}}, \mathrm{m}$, $\left.\mathrm{CH}_{\text {arom }}\right) ;{ }^{13} \mathrm{C}$ NMR (DMSO- $\left.d_{6}\right), \delta$ (ppm): 12.45, 14.90, 47.66, 48.16, 58.60, 63.24, 93.40, 127.37, 127.44, $127.86,128.82,129.21,129.31,132.63,136.83,161.46,165.36,173.83,175.64 ;$ HRMS-ESI, $m / z\left([\mathrm{M}+\mathrm{H}]^{+}\right)$, calcd for $\mathrm{C}_{23} \mathrm{H}_{22} \mathrm{~N}_{2} \mathrm{O}_{4}+\mathrm{H}^{+} 391.1654$, found 391.1652.

(3aS,6aR)-Ethyl 1-methoxybenzyl-2-methyl-4,6-dioxo-5-phenyl-1,3a,4,5,6,6a-hexahydropyrrolo[3,4-b]pyrrole3-carboxylate 8b. 0.65 g; yield 77\%; m.p. $152-153{ }^{\circ} \mathrm{C} ;{ }^{1} \mathrm{H}$ NMR (DMSO- $\left.d_{6}\right), \delta(\mathrm{ppm}): 1.20(3 \mathrm{H}, \mathrm{t}$, $\left.J=7.1 \mathrm{~Hz}, \mathrm{CH}_{3} \mathrm{CH}_{2} \mathrm{O}\right) ; 2.33\left(3 \mathrm{H}, \mathrm{s}, \mathrm{CH}_{3}-\mathrm{Het}\right) ; 3.75(3 \mathrm{H}, \mathrm{s}, \mathrm{MeO}) ; 3.99-4.13\left(2 \mathrm{H}, \mathrm{m}, \mathrm{CH}_{3} \mathrm{CH}_{2} \mathrm{O}\right) ; 4.29$ $(1 \mathrm{H}$, br. d, $J=10.5 \mathrm{~Hz}, \mathrm{H}-6 \mathrm{a}) ; 4.48\left(1 \mathrm{H}, \mathrm{d}, J=16.2 \mathrm{~Hz}, \mathrm{CH}_{2} \mathrm{Ph}\right) ; 4.49(1 \mathrm{H}, \mathrm{d}, J=10.5 \mathrm{~Hz}, \mathrm{H}-3 \mathrm{a}) ; 4.73$ (1H, $\left.\mathrm{d}, J=16.2 \mathrm{~Hz}, \mathrm{CH}_{2} \mathrm{Ph}\right) ; 6.96\left(2 \mathrm{H}, \mathrm{d}, J=8.6 \mathrm{~Hz}, \mathrm{CH}_{\text {arom }}\right) ; 7.19\left(2 \mathrm{H}, \mathrm{d}, J=8.6 \mathrm{~Hz}, \mathrm{CH}_{\text {arom }}\right) ; 7.23-7.26$ $\left(1 \mathrm{H}, \mathrm{m}, \mathrm{CH}_{\text {arom }}\right) ; 7.35-7.37\left(1 \mathrm{H}, \mathrm{m}, \mathrm{CH}_{\text {arom }}\right) ; 7.40-7.44\left(1 \mathrm{H}, \mathrm{m}, \mathrm{CH}_{\text {arom }}\right) ; 7.47-7.51\left(2 \mathrm{H}, \mathrm{m}, \mathrm{CH}_{\text {arom }}\right)$; ${ }^{13}$ C NMR (DMSO- $\left.d_{6}\right), \delta$ (ppm): 12.48, 14.90, 47.59, 47.62, 55.48, 58.57, 62.88, 93.32, 114.60, 127.38, 128.32, $128.82,129.07,129.31,132.63,159.09,161.35,165.36,173.86,175.65 ;$ HRMS-ESI, $m / z\left([\mathrm{M}+\mathrm{H}]^{+}\right)$, calcd $^{2}$ for $\mathrm{C}_{24} \mathrm{H}_{24} \mathrm{~N}_{2} \mathrm{O}_{5}+\mathrm{H}^{+} 421.1759$, found 421.1754 . 
(3aS,6aR)-Ethyl 5-(4-ethylphenyl)-2-methyl-4,6-dioxo-1-phenetyl-1,3a,4,5,6,6a-hexahydropyrrolo[3,4-b] pyrrole-3-carboxylate 8c. 0.70 g; yield 82\%; m.p. 147-149 ${ }^{\circ} \mathrm{C} ;{ }^{1} \mathrm{H}$ NMR (DMSO- $\left.d_{6}\right), \delta(\mathrm{ppm}): 1.18(3 \mathrm{H}, \mathrm{t}$, $\left.J=7.1 \mathrm{~Hz}, 4-\mathrm{CH}_{3} \mathrm{CH}_{2} \mathrm{C}_{6} \mathrm{H}_{4}\right) ; 1.20\left(3 \mathrm{H}, \mathrm{t}, J=7.6 \mathrm{~Hz}, \mathrm{CH}_{3} \mathrm{CH}_{2} \mathrm{O}\right) ; 2.07\left(3 \mathrm{H}, \mathrm{s}, \mathrm{CH}_{3}-\mathrm{Het}\right) ; 2.64(2 \mathrm{H}, \mathrm{q}$, $\left.J=7.1 \mathrm{~Hz}, 4-\mathrm{CH}_{3} \mathrm{CH}_{2} \mathrm{C}_{6} \mathrm{H}_{4}\right) ; 2.80-2.87\left(1 \mathrm{H}, \mathrm{m}, \mathrm{CH}_{2} \mathrm{CH}_{2} \mathrm{Ph}\right) ; 2.92-2.99\left(1 \mathrm{H}, \mathrm{m}, \mathrm{CH}_{2} \mathrm{CH}_{2} \mathrm{Ph}\right) ; 3.60-3.70$ $\left(2 \mathrm{H}, \mathrm{m}, \mathrm{CH}_{2} \mathrm{CH}_{2} \mathrm{Ph}\right) ; 3.96-4.10\left(2 \mathrm{H}, \mathrm{m}, \mathrm{CH}_{3} \mathrm{CH}_{2} \mathrm{O}\right) ; 4.28(1 \mathrm{H}, \mathrm{dd}, J=10.5 \mathrm{~Hz}, \mathrm{~J}=1.1 \mathrm{~Hz}, \mathrm{H}-6 \mathrm{a}) ; 4.75$ $(1 \mathrm{H}, \mathrm{d}, \mathrm{J}=10.5 \mathrm{~Hz}, \mathrm{H}-3 \mathrm{a}) ; 7.14-7.17\left(2 \mathrm{H}, \mathrm{m}, \mathrm{CH}_{\text {arom }}\right) ; 7.21-7.26\left(3 \mathrm{H}, \mathrm{m}, \mathrm{CH}_{\text {arom }}\right) ; 7.30-7.34$ (4H, m, $\left.\mathrm{CH}_{\text {arom }}\right) ;{ }^{13} \mathrm{C}$ NMR (DMSO- $\left.d_{6}\right), \delta$ (ppm): 11.98, 14.90, 15.84, 28.21, 33.53, 46.93, 47.62, 58.43, 63.67, 92.92, $126.81,127.25,128.63,128.88,129.25,130.24,139.14,144.54,161.61,165.30,174.33,175.75 ;$ HRMS-ESI, $m / z\left([\mathrm{M}+\mathrm{H}]^{+}\right)$, calcd for $\mathrm{C}_{26} \mathrm{H}_{28} \mathrm{~N}_{2} \mathrm{O}_{4}+\mathrm{H}^{+} 433.2123$, found 433.2128 .

X-Ray Crystallographic data for 8c. CCDC 1574386 contains the supplementary crystallographic data for this paper. These data can be obtained free of charge via http:/ / www.ccdc.cam.ac.uk/conts/retrieving. html (or from the CCDC, 12 Union Road, Cambridge CB2 1EZ, UK; Fax: +44-1223-336033; E-mail: deposit@ccdc.cam.ac.uk). Crystal data for $\mathrm{C}_{26} \mathrm{H}_{28} \mathrm{~N}_{2} \mathrm{O}_{4}(\mathrm{M}=432.50 \mathrm{~g} / \mathrm{mol})$ : monoclinic, space group $\mathrm{P} 21 / \mathrm{n}$ (no. 14), $\mathrm{a}=15.0252(9) \AA, \mathrm{b}=8.6768(5) \AA, \mathrm{c}=17.3436(10) \AA, \alpha=90^{\circ}, \beta=97.7760(10)^{\circ}, \gamma=90^{\circ}$ $\mathrm{V}=2240.3(2) \AA 33, \mathrm{Z}=4, \mathrm{~T}=120(2) \mathrm{K}, \mu(\mathrm{CuK} \alpha)=0.087 \mathrm{~mm}-1$, Dcalc $=1.282 \mathrm{~g} / \mathrm{cm}^{3} .20916$ reflections measured $\left(4.74^{\circ} \leq 2 \Theta \leq 51.992^{\circ}\right), 4387$ unique (Rint $=0.0380$, Rsigma $\left.=0.0411\right)$ which were used in all

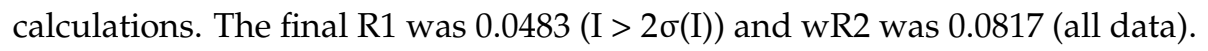

(3aS,6aR)-Ethyl 5-(4-ethoxyphenyl)-2-methyl-4,6-dioxo-1-phenetyl-1,3a,4,5,6,6a-hexahydropyrrolo[3,4-b] pyrrole-3-carboxylate 8d. 0.66 g; yield 73\%; m.p. $164-166{ }^{\circ} \mathrm{C} ;{ }^{1} \mathrm{H}$ NMR (DMSO- $\left.d_{6}\right), \delta(\mathrm{ppm}): 1.20(3 \mathrm{H}, \mathrm{t}$, $\left.J=7.0 \mathrm{~Hz}, \mathrm{CH}_{3} \mathrm{CH}_{2} \mathrm{O}\right) ; 1.34\left(3 \mathrm{H}, \mathrm{t}, J=7.0 \mathrm{~Hz}, 4-\mathrm{CH}_{3} \mathrm{CH}_{2} \mathrm{OC}_{6} \mathrm{H}_{4}\right) ; 2.06(3 \mathrm{H}, \mathrm{s}, \mathrm{CH} \underline{3}-\mathrm{Het}) ; 2.78-2.87$ $\left(1 \mathrm{H}, \mathrm{m}, \mathrm{CH}_{2} \mathrm{CH}_{2} \mathrm{Ph}\right) ; 2.91-2.96\left(1 \mathrm{H}, \mathrm{m}, \mathrm{CH}_{2} \mathrm{CH}_{2} \mathrm{Ph}\right) ; 3.60-3.69$ (2H, m, $\left.\mathrm{CH}_{2} \mathrm{CH}_{2} \mathrm{Ph}\right) ; 4.04-4.12(4 \mathrm{H}, \mathrm{m}$, $\left.2 \mathrm{CH}_{3} \mathrm{CH}_{2}\right) ; 4.27(1 \mathrm{H}$, br.d, $J=10.5 \mathrm{~Hz}, \mathrm{H}-6 \mathrm{a}) ; 4.74(1 \mathrm{H}, \mathrm{d}, J=10.5 \mathrm{~Hz}, \mathrm{H}-3 \mathrm{a}) ; 7.01(2 \mathrm{H}, \mathrm{d}, J=8.7 \mathrm{~Hz}$, $\left.\mathrm{CH}_{\text {arom }}\right) ; 7.15\left(2 \mathrm{H}, \mathrm{d}, J=8.7 \mathrm{~Hz}, \mathrm{CH}_{\text {arom }}\right) ; 7.23-7.26\left(3 \mathrm{H}, \mathrm{m}, \mathrm{CH}_{\text {arom }}\right) ; 7.30-7.33\left(2 \mathrm{H}, \mathrm{m}, \mathrm{CH}_{\text {arom }}\right)$; ${ }^{13}$ C NMR (DMSO- $d_{6}$ ), $\delta$ (ppm): 11.97, 14.91, 14.96, 33.53, 46.91, 47.54, 58.42, 63.59, 63.70, 92.91, 114.96, $124.99,126.81,128.58,128.88,129.25,139.15,158.63,161.58,165.31,174.42,175.86 ;$ HRMS-ESI, $m / z$ ([M $+\mathrm{H}^{+}$), calcd. for $\mathrm{C}_{26} \mathrm{H}_{28} \mathrm{~N}_{2} \mathrm{O}_{5}+\mathrm{H}^{+} 449.2073$, found 449.2067 .

(3aS,6aR)-Ethyl 1-benzyl-2-methyl-4,6-dioxo-5-(3,4-dichlorophenyl)-1,3a,4,5,6,6a-hexahydropyrrolo[3,4-b] pyrrole-3-carboxylate 8e. 0.64 g; yield 70\%; m.p. $146-147{ }^{\circ} \mathrm{C} ;{ }^{1} \mathrm{H}$ NMR (DMSO- $\left.d_{6}\right), \delta$ (ppm): 1.20 $\left(3 \mathrm{H}, \mathrm{t}, J=7.1 \mathrm{~Hz}, \mathrm{CH}_{3} \mathrm{CH}_{2} \mathrm{O}\right) ; 2.31\left(3 \mathrm{H}, \mathrm{s}, \mathrm{CH}_{3}-\mathrm{Het}\right) ; 4.00-4.14\left(2 \mathrm{H}, \mathrm{m}, \mathrm{CH}_{3} \mathrm{CH}_{2} \mathrm{O}\right) ; 4.33$ (1H, br.d, $J=10.5 \mathrm{~Hz}, \mathrm{H}-6 \mathrm{a}) ; 4.52(1 \mathrm{H}, \mathrm{d}, J=10.5 \mathrm{~Hz}, \mathrm{H}-3 \mathrm{a}) ; 4.59\left(1 \mathrm{H}, \mathrm{d}, J=16.7 \mathrm{~Hz}, \mathrm{CH}_{2} \mathrm{Ph}\right) ; 4.78(1 \mathrm{H}, \mathrm{d}, J=$ $\left.16.7 \mathrm{~Hz}, \mathrm{CH}_{2} \mathrm{Ph}\right) ; 7.25\left(2 \mathrm{H}, \mathrm{d}, J=7.4 \mathrm{~Hz}, \mathrm{CH}_{\text {arom }}\right) ; 7.30-7.34\left(2 \mathrm{H}, \mathrm{m}, \mathrm{CH}_{\text {arom }}\right) ; 7.40(2 \mathrm{H}, \mathrm{t}, J=7.5 \mathrm{~Hz}$, $\left.\mathrm{CH}_{\text {arom }}\right) ; 7.61\left(1 \mathrm{H}, \mathrm{d}, J=2.3 \mathrm{~Hz}, \mathrm{CH}_{\text {arom }}\right) ; 7.79\left(1 \mathrm{H}, \mathrm{d}, J=8.6 \mathrm{~Hz}, \mathrm{CH}_{\text {arom }}\right) ;{ }^{13} \mathrm{C}$ NMR $\left(\mathrm{DMSO}-d_{6}\right)$, $\delta$ (ppm): 12.48, 14.90, 47.74, 48.12, 58.60, 63.15, 93.12, 127.49, 127.75, 127.87, 129.19, 129.27, 131.30, $131.53,131.61,132.52,136.76,161.61,165.29,173.27,175.11$; HRMS-ESI, $m / z\left([M+H]^{+}\right)$, calcd for $\mathrm{C}_{23} \mathrm{H}_{20} \mathrm{Cl}_{2} \mathrm{~N}_{2} \mathrm{O}_{4}+\mathrm{H}^{+} 459.0874$, found 459.0868 .

(3aS,6aR)-Ethyl 5-(3,4-dichlorophenyl)-2-methyl-4,6-dioxo-1-phenetyl-1,3a,4,5,6,6a-hexahydropyrrolo[3,4-b] pyrrole-3-carboxylate 8f. 0.65 g; yield 69\%; m.p. $155-156{ }^{\circ} \mathrm{C} ;{ }^{1} \mathrm{H}$ NMR (DMSO- $\left.d_{6}\right), \delta(\mathrm{ppm}): 1.18(3 \mathrm{H}$, $\left.\mathrm{t}, J=7.1 \mathrm{~Hz}, \mathrm{CH}_{3} \mathrm{CH}_{2} \mathrm{O}\right) ; 2.08\left(3 \mathrm{H}, \mathrm{s}, \mathrm{CH}_{3}-\mathrm{Het}\right) ; 2.81-2.88\left(1 \mathrm{H}, \mathrm{m}, \mathrm{CH}_{2} \mathrm{CH}_{2} \mathrm{Ph}\right) ; 2.93-2.99(1 \mathrm{H}, \mathrm{m}$, $\left.\mathrm{CH}_{2} \mathrm{CH}_{2} \mathrm{Ph}\right) ; 3.60-3.67\left(2 \mathrm{H}, \mathrm{m}, \mathrm{CH}_{2} \mathrm{CH}_{2} \mathrm{Ph}\right) ; 3.98-4.10\left(2 \mathrm{H}, \mathrm{m}, \mathrm{CH}_{3} \mathrm{CH}_{2}\right) ; 4.28(1 \mathrm{H}, \mathrm{dd}, J=10.6 \mathrm{~Hz}, J=$ $1.0 \mathrm{~Hz}, \mathrm{H}-6 \mathrm{a}) ; 4.75(1 \mathrm{H}, \mathrm{d}, J=10.6 \mathrm{~Hz}, \mathrm{H}-3 \mathrm{a}) ; 7.22-7.27\left(3 \mathrm{H}, \mathrm{m}, \mathrm{CH}_{\text {arom }}\right) ; 7.30-7.35\left(3 \mathrm{H}, \mathrm{m}, \mathrm{CH}_{\text {arom }}\right) ; 7.64$ $\left(1 \mathrm{H}, \mathrm{d}, J=2.3 \mathrm{~Hz}, \mathrm{CH}_{\text {arom }}\right) ; 7.79\left(1 \mathrm{H}, \mathrm{d}, J=8.6 \mathrm{~Hz}, \mathrm{CH}_{\text {arom }}\right) ;{ }^{13} \mathrm{C}$ NMR (DMSO- $\left.d_{6}\right), \delta(\mathrm{ppm}): 12.05,14.91$, 14.96, 33.48, 46.81, 47.74, 58.45, 63.56, 92.63, 126.82, 127.83, 128.88, 129.01, 129.25, 129.32, 131.31, 131.53, $131.60,132.58,139.14,161.80,165.23,173.69,175.14 ; \mathrm{HRMS}, m / z\left([\mathrm{M}+\mathrm{H}]^{+}\right)$, calcd for $\mathrm{C}_{24} \mathrm{H}_{22} \mathrm{Cl}_{2} \mathrm{~N}_{2} \mathrm{O}_{4}$ $+\mathrm{H}^{+}$473.1031, found 473.1024.

\section{Conclusions}

Herein, we presented the new unusual variant of the realization of the Hantzsch-type synthetic scheme $\mathrm{C}-\mathrm{C}+\mathrm{C}-\mathrm{C}-\mathrm{N}$ for the synthesis of polyhydrogenated pyrrolo[3,4- $b]$ pyrroles based on the 
cyclization of bromomaleimides with aminocrotonic acid esters. A domino-reaction proceeds chemoand stereoselectively and involves the steps of intermolecular nucleophilic $\mathrm{C}$-addition or substitution and intramolecular nucleophilic $\mathrm{N}$-addition both in two- and multicomponent mode.

Supplementary Materials: The NMR spectra, data of HPLC-MS-ESI analysis of pyrrolopyrroles 8 and crystallographic data for $8 \mathrm{c}$ are available online.

Acknowledgments: This work was supported by the Ministry of Education and Science of the Russian Federation (Agreement number 02.a03.21.0008).

Author Contributions: K. Shikhaliev conceived and designed the experiments; A. Sabynin and V. Sekirin performed the experiments; K. Yankina and F. Zubkov analyzed the data; M. Krysin wrote the paper.

Conflicts of Interest: The authors declare no conflict of interest.

\section{References}

1. Krzeszewski, M.; Gryko, D.; Gryko, D.T. The tetraarylpyrrolo[3,2-b]pyrroles-from serendipitous discovery to promising heterocyclic optoelectronic materials. Acc. Chem. Res. 2017, 50, 2334-2345. [CrossRef] [PubMed]

2. Li, Y. Molecular design of photovoltaic materials for polymer solar sells: Toward suitable electronic energy levels and broad absorption. Acc. Chem. Res. 2012, 45, 723-733. [CrossRef] [PubMed]

3. Ghorpade, T.K.; Patri, M.; Mishra, S.P. Highly sensitive colorimetric and fluorometric anion sensors based on mono and di-calix[4]pyrrole substituted diketopyrrolopyrroles. Sens. Actuators B Chem. 2016, 225, 428-435. [CrossRef]

4. Wiktorowski, S.; Christelle, R.; Winterhalder, M.; Daltrozzo, E.; Zumbusch, A. Water-soluble pyrrolopyrrole cyanine (PPCy) NIR fluorophores. Chem. Commun. 2014, 50, 4755-4758. [CrossRef] [PubMed]

5. Vala, M.; Vyňuchal, J.; Toman, P.; Weiter, M.; Luňák, S., Jr. Novel, soluble diphenyl-diketo-pyrrolopyrroles: Experimental and theoretical study. Dyes Pigments 2010, 84, 176-182. [CrossRef]

6. Mizuguchi, J.; Shikamori, H. Spectral and Crystallographic Coincidence in a Mixed Crystal of Two Components and a Crystal of Their Hybrid Component in Pyrrolopyrrole Pigments. J. Phys. Chem. B 2004, 108, 2154-2161. [CrossRef]

7. Cordes, J.; Harms, K.; Koert, U. Synthesis of the Isoquinocycline-Pyrrolopyrrole Substructure. Org. Lett. 2010, 12, 3808-3811. [CrossRef] [PubMed]

8. Muchowski, J.M.; Unger, S.H.; Ackrell, J.; Cheung, P.; Cooper, G.F.; Cook, J.; Gallegra, P.; Halpern, O.; Koehler, R.; Kluge, A.F. Synthesis and Antiinflammatory and Analgesic Activity of 5-Aroyl-1,2-dihydro-3H-pyrrolo[1,2-a]pyrrole-1-carboxylic Acids and Related Compounds. J. Med. Chem. 1989, 32, 1202-1207. [CrossRef] [PubMed]

9. Zhou, H.; Che, X.; Bao, G.; Wang, N.; Peng, L.; Barnash, K.D.; Frye, S.V.; James, L.I.; Bai, X. Design, synthesis, and protein methyltransferase activity of a unique set of constrained amine containing compounds. Bioorg. Med. Chem. Lett. 2016, 26, 4436-4440. [CrossRef] [PubMed]

10. Trunkfield, A.E.; Gurcha, S.S.; Gurdyal, S.B.; Timothy, D.H. Inhibition of Escherichia coli glycosyltransferase MurG and Mycobacterium tuberculosis Gal transferase by uridine-linked transition state mimics. Bioorg. Med. Chem. 2010, 18, 2651-2663. [CrossRef] [PubMed]

11. Russell, M.G.; Beer, M.S.; Stanton, J.A.; Sohal, B.; Castro, J.L. 2,7-Diazabicyclo[3.3.0]octanes as novel h5-HT $1 \mathrm{D}$ receptor agonists. Bioorg. Med. Chem. Lett. 1999, 9, 2491-2496. [CrossRef]

12. Huck, B.R.; Llamas, L.; Robarge, M.J.; Dent, T.C.; Song, J.; Hodnick, W.F.; Crumrine, C.; Stricker-Krongrad, A.; Harrington, J. The identification of pyrimidine-diazabicyclo[3.3.0]octane derivatives as 5- $\mathrm{HT}_{2 \mathrm{C}}$ receptor agonists. Bioorg. Med. Chem. Lett. 2006, 16, 2891-2894. [CrossRef] [PubMed]

13. Ivashchenko, A.A.; Ivashchenko, A.V.; Tkachenko, S.E.; Okun, M.; Savchuk, N.F. Ligands for 5-HT6, Pharmaceutical Composition, Method for Their Production and Use Thereof. U.S. Patent Application No. 2011/0046368 A1, 24 February 2011.

14. Chang, L.L.; Yang, G.X.; McCauley, E.; Mumford, R.A.; Schmidt, J.A.; Hagmann, W.K. Constraining the amide bond in N-Sulfonylated dipeptide VLA-4 antagonists. Bioorg. Med. Chem. Lett. 2008, 18, 1688-1691. [CrossRef] [PubMed] 
15. Ma, Z.; Chu, D.T.W.; Cooper, C.S.; Li, Q.; Fung, A.K.L.; Wang, S.; Fung, S.W.; Shen, L.L.; Flamm, R.K.;

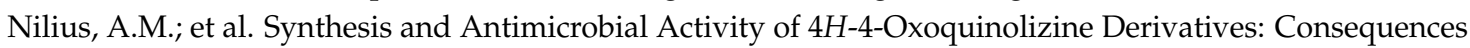
of Structural Modification at the C-8 Position. J. Med. Chem. 1999, 42, 4202-4213. [CrossRef] [PubMed]

16. Schenke, T.; Petersen, U. Preparation of 2,7-Diazabicyclo[3,3,0]octanes. U.S. Patent 5,071,999, 10 December 1991.

17. Pedrosa, R.; Andrés, C.; Andrés, L.; Nieto, J. A Novel Synthesis of Enantiopure Octahydropyrrolo[3,4- $b$ ] pyrroles by Intramolecular [3 + 2] Dipolar Cycloaddition on Chiral Perhydro-1,3-benzoxazines. Org. Lett. 2002, 4, 2513-2516. [CrossRef] [PubMed]

18. Pedrosa, R.; Andrés, C.; Nieto, J.; Pérez-Cuadrado, C.; San Francisco, I. An Efficient and Diastereoselective Intramolecular 1,3-Dipolar Cycloaddition of Cyclic Azomethine Ylides and Nitrones. Eur. J. Org. Chem. 2006, 14, 3259-3265. [CrossRef]

19. Poornachandran, M.; Raghunathan, R. A novel entry into 1-methyl- and 1-aryl-octahydropyrrolo[3,4- $b]$ pyrroles and their N-1-C-2 fused derivatives: Stereoselective synthesis via an intramolecular azomethine ylide cycloaddition reaction. Tetrahedron Lett. 2005, 46, 7197-7200. [CrossRef]

20. Poornachandran, M.; Raghunathan, R. Synthesis of pyrrolo[3,4-b]pyrroles and perhydrothiazolo-[3' $\left.4^{\prime}-2,3\right]$ pyrrolo[4,5-c]pyrroles. Tetrahedron 2008, 64, 6461-6474. [CrossRef]

21. Poornachandran, M.; Raghunathan, R. Facile Synthesis of cis-Fused 1-Benzyl/-H-5-arylsulfonyl Pyrrolo[3,4-b]pyrroles. Synth. Commun. 2009, 39, 917-926. [CrossRef]

22. Morin, M.S.T.; Aly, S.; Arndtsen, B.A. Phosphonite mediated 1,3-dipolar cycloaddition: A route to polycyclic 2-pyrrolines from imines, acid chlorides and alkenes. Chem. Commun. 2013, 49, 883-885. [CrossRef] [PubMed]

23. Kang, S.-K.; Kim, K.-J.; Hong, Y.-T. Synthesis of $\alpha$-Methylene- $\gamma$-butyrolactones: Ru-Catalyzed Cyclocarbonylation of Allenyl Aldehydes and Allenyl Ketones. Angew. Chem. Int. Ed. 2002, 41, 1584-1586. [CrossRef]

24. Kim, S.H.; Kang, E.S.; Yu, C.M. A Cyclocarbonylation for the Synthesis of Bicyclic 3-Methylene-1 -phthalimidoylbutyrolactams from Allene-hydrazones Mediated by Mo(CO) 6 . Synlett 2007, 15, 2439-2441. [CrossRef]

25. Lee, J.W.; Son, H.J.; Lee, J.H.; Yoon, G.J.; Park, M.H. Synthesis of 2,7-Diazabicyclo[3.3.0]octane Derivatives via Intramolecular Cyclization Reaction. Synth. Commun. 1996, 26, 89-94. [CrossRef]

26. Lee, J.W.; Son, H.J.; Jung, Y.E.; Lee, J.H. Synthesis of 2,7-Diazabicyclo[3.3.0]octane and 2,7-Diazabicyclo oct-4-ene Derivatives via Cyclization Reaction and Julia Reaction. Synth. Commun. 1996, 26, 1499-1505. [CrossRef]

27. Attanasi, J.A.; Bianchi, L.; De Crescentini, L.; Favi, G.; Mantellini, F. Easy One-Pot Synthesis of Fused Heterocycles from 1,2-Diaza-1,3-dienes. Eur. J. Org. Chem. 2011, 2924-2927. [CrossRef]

28. Guillaume, J.; Lubell, W.D. Synthesis of Fused Heteroarylprolines and Pyrrolopyrroles. J. Org. Chem. 2004, $69,4656-4662$.

29. Lee, S.; Chataigner, I.; Piettre, S.R. Facile Dearomatization of Nitrobenzene Derivatives and Other Nitroarenes with N-Benzyl Azomethine Ylide. Angew. Chem. Int. Ed. 2011, 50, 472-476. [CrossRef] [PubMed]

30. Liu, H.; Zheng, C.; You, S.-L. Catalytic C6 Functionalization of 2,3-Disubstituted Indoles by Scandium Triflate. J. Org. Chem. 2014, 79, 1047-1054. [CrossRef] [PubMed]

31. Yang, Y.; Ren, H.-X.; Chen, F.; Zhang, Z.-B.; Zou, Y.; Chen, C.; Song, X.-J.; Tian, F.; Peng, L.; Wang, L.-X. Organocatalytic Asymmetric Annulation between Hydroxymaleimides and Nitrosoarenes: Stereoselective Preparation of Chiral Quaternary N-Hydroxyindolines. Org. Lett. 2017, 19, 2805-2808. [CrossRef] [PubMed]

32. Rostovskii, N.V.; Novikov, M.S.; Khlebnikov, A.F.; Korneev, S.M.; Yufit, D.S. Cu(II)-catalyzed domino reaction of $2 \mathrm{H}$-azirines with diazotetramic and diazotetronic acids. Synthesis of 2-substituted 2H-1,2,3-triazoles. Org. Biomol. Chem. 2013, 11, 5535-5545. [CrossRef] [PubMed]

33. Rostovskii, N.V.; Sakharov, P.A.; Novikov, M.S.; Khlebnikov, A.F.; Starova, G.L. Cu(I)-NHC-Catalyzed $(2+3)$-Annulation of Tetramic Acids with $2 H$-Azirines: Stereoselective Synthesis of Functionalized Hexahydropyrrolo[3,4-b]pyrroles. Org. Lett. 2015, 17, 4148-4151. [CrossRef] [PubMed]

34. Zhu, J.-N.; Chen, L.-L.; Zhou, R.-X.; Li, B.; Shao, Z.-Y.; Zhao, S.-Y. Copper-Catalyzed Oxidative Cyclization of Maleimides with Amines and Alkyne Esters: Direct Access to Fully Substituted Dihydropyrroles and Pyrrole Derivatives. Org. Lett. 2017, 19, 6044-6047. [CrossRef] [PubMed] 
35. Vandyshev, D.Y.; Shikhaliev, K.S.; Potapov, A.Y.; Krysin, M.Y. Condensation of 1,2-diamino-4phenylimidazole and $N$-arylmaleimides with the formation of new tetrahydroimidazo[1,5-b]pyridazines. Chem. Heterocycl. Comp. 2015, 51, 829-833. [CrossRef]

36. Vandyshev, D.Y.; Shikhaliev, K.S.; Kokonova, A.V.; Potapov, A.Y.; Kolpakova, M.G.; Sabynin, A.L.; Zubkov, F.I. A novel method for the synthesis of pyrimido[1,2-a]benzimidazoles. Chem. Heterocycl. Comp. 2016, 52, 493-497. [CrossRef]

37. Rudenko, R.V.; Komykhov, S.A.; Desenko, S.M.; Sen'ko, Y.V.; Shishkin, O.V.; Konovalova, I.S.; Shishkina, S.V.; Chebanov, V.A. A Comprehensive Study of the Heterocyclizations of N-Arylmaleimides and 6-Aminouracils. Synthesis 2011, 3161-3167. [CrossRef]

38. Havrylyuk, D.; Zimenkovsky, B.; Lesyk, R. Synthesis and Anticancer Activity of Novel Nonfused Bicyclic Thiazolidinone Derivatives. Phosphorus Sulfur Silicon Relat. Elem. 2009, 184, 638-650. [CrossRef]

39. Lesyk, R.; Vladzimirska, O.; Holota, S.; Zaprutko, L.; Gzella, A. New 5-substituted thiazolo[3,2-b][1,2,4] triazol-6-ones: Synthesis and anticancer evaluation. Eur. J. Med. Chem. 2007, 42, 641-648. [CrossRef] [PubMed]

40. Shah, K.R.; DeWitt Blanton, C. Reaction of Maleimides and Ethyl 3-Aminocrotonates, a Reinvesiation Leading to an Improved Synthesis of Pyrrolo[3,4-c] pyridines. J. Org. Chem. 1982, 47, 502-508. [CrossRef]

41. Banwella, M.G.; Jonesa, M.T.; Loonga, D.T.; Luptona, D.W.; Pinkertona, D.M.; Rayb, J.K.; Willisa, A.S. A Pd[0]-catalyzed Ullmann cross-coupling/reductive cyclization approach to C-3 mono-alkylated oxindoles and related compounds. Tetrahedron 2010, 66, 9252-9262. [CrossRef]

42. Kuckländer, U.; Hühnermann, W. Beobachtungen zum Mechanismus der Nenitzescu-Reaktion Synthese von 6-Hydroxy-indol-Derivaten. Arch. Pharm. 1979, 312, 515-526. [CrossRef]

43. George, R.; Allen, G.R., Jr.; Pidacks, C.; Weiss, M.J. The Mitomycin Antibiotics. Synthetic Studies. XIV. ${ }^{1}$ the $^{2}$ Nenitzescu Indole Synthesis. Formation of Isomeric Indoles and Reaction Mechanism. J. Am. Chem. Soc. 1966, 88, 2536-2544.

44. Zhang, Y.; Chen, F.; Yang, Y.; Tang, C.-Z.; Tian, F.; Peng, L.; Wang, L.-X. An unexpected metal-free DMAP catalyzed Michael addition-elimination domino reaction between 2-naphthols and bromomaleimides for the effective construction of 3-arylmaleimides. Tetrahedron Lett. 2016, 57, 1261-1264. [CrossRef]

45. Estevez, V.; Villacampa, M.; Menéndez, J.C. Recent advances in the synthesis of pyrroles by multicomponent reactions. Chem. Soc. Rev. 2014, 43, 4633-4657. [CrossRef] [PubMed]

46. Moss, T.A.; Nowak, T. Synthesis of 2,3-dicarbonylated pyrroles and furans via the three-component Hantzsch reaction. Tetrahedron Lett. 2012, 53, 3056-3060. [CrossRef]

47. Li, X.; Li, H.; Yang, W.; Zhuang, J.; Wang, W. A mild and selective protecting and reversed modification of thiols. Tetrahedron Lett. 2016, 57, 2660-2663. [CrossRef]

Sample Availability: Samples of the compounds $\mathbf{8}$ are available from the authors.

(C) 2017 by the authors. Licensee MDPI, Basel, Switzerland. This article is an open access article distributed under the terms and conditions of the Creative Commons Attribution (CC BY) license (http://creativecommons.org/licenses/by/4.0/). 